DOI: 10.22559/folklor.1056

folklor/edebiyat, cilt: 25 , sayl: 100, 2019/4

\title{
Türk Destanlarında "Ant İçme" Ritüeli Üzerine Bazı Tespitler
}

\section{Some Determinations on "Take an Oath" Ritual in Turkic Epic}

\section{Abdulselam Arvas*}

Öz

Bu makalede, Türk destanlarında yer alan "ant içme" törenleri üzerine bir araştırma yapılmıştır. Bu yüzden, öncelikle, “ant”ın ne anlama geldiği üzerinde durulmuş ve bu kavramın tanımı yapılmıştır. Daha sonra ise "ant” müessesesinin Türklerdeki tarihsel süreci hakkında kısa bilgiler verilmiş ve "ant" $1 n$ ne kadar eskiye gittiği örnekler üzerinden anlatılmıştır. Bu kapsamda "ant"ın sadece tarihsel ve kültürel bir hadise olmadığı, Türk edebiyatına da yansıdığı görülmüştür. Yani, bu kısma kadar “ant” töreninin tarihî derinlikten bugüne doğru hikâyesi özet hâlinde aktarılmıştır.

Bu temel bilgilerden sonra "ant içme" ritüelinin Türk destanlarındaki yeri irdelenmiştir. Onun için Türk dünyasından yirmi destan metni incelenmiş ve bunlardaki örnekler ilgili başlıklar altında analiz edilmiştir. Buna göre, Türk destanlarında yer alan "ant içme" geleneği temelde iki işleve sahiptir ancak bunlar çeşitli alt başlıklar altında tasnif edilebilir. Türk destanlarına yansıyan "ant içme" töreninin ilk işlevi sadece söze dayanır ve bu yüzden destandaki toplum üzerinde çok etkili değildir. Bu ilk tip "ant”"ta, kişi verdiği söze dair ağır bir mesuliyet taşımaz. "Ant”"ın diğer işlevi ise hem geleneksel ve etkili hem de komplike bir ritüel olduğu için bağlayıcıdır. Yani bu tip "ant” kolay kolay göz ardı edilemez. Kısaca, bu araştırmada "ant içme" ritüelinin Türk destanlarına yansıma biçimleri ele alınmıştır.

Anahtar sözcükler: Türkler, destan, gelenek, ant içme, ritüel

* Doç. Dr., Çankırı Karatekin Üniversitesi, Edebiyat Fakültesi, Türk Dili ve Edebiyatı Bölümü. arvasnarin@gmail. com. ORCID ID: 0000-0002-7553-183X. 


\begin{abstract}
In this article, a research has been conducted on "take an oath" ceremonies in Turkic epics. Therefore, firstly, the meaning of the oath is emphasized and this term is defined. Then, brief information was given about the historical process of the oath institution in the Turks and with examples are explained that goes how old of "the oath". In this context, it was seen that oath is not only a historical and cultural phenomenon, but also reflected in Turkish literature. So, until this part, the story of the oath ceremony has been told from the historical depth to the present in brief.

After this basic information, the place of "take an oath" ritual in Turkic epics is examined. For this reason, twenty epics from the Turkic world were investigated and the examples in these epics were analyzed under related headings. Accordingly, the tradition of "taken an oath" in Turkic epics has basically two functions, however, these can be classified under various subheadings. The first function of "take an oath" ritual reflected in the Turkic epics is based solely on words, and so it is not very effective on the society in the epic. In this first type of "oath" the person does not bear a heavy responsibility for the promise. The other function of the oath is binding because it is both a traditional and effective and complex ritual. So, this kind of "oath" cannot be easily ignored. In short, the reflection formats of the "take an oath" ritual to the Turkic epics is discussed in this research.
\end{abstract}

Keywords: Turks, epic, traditional, take an oath, ritual

\title{
Giriş
}

Evrensel bir hadise olduğu için her milletin kültür tarihinde mevcut bir kavram olan "ant" Türkçede "söz ver-", "yemin et-", "ahd et-" gibi çeşitli kelime gruplarıyla ifade edilmektedir. Bu eylemin ifade ettiği esas anlam, mümkün olan bir durumu veya geleceğe dair herhangi bir husus için yapılan vaadi yerine getirmektir. Örneğin bir kişinin borcunu ödeyeceğini, bir yerde hazır bulunacağını, bir işi yapacağını söylemesi "söz verme" ile "vaat"lere dayanır. Yani bir kişi tarafindan öteki kişiye belli bir konuda herhangi bir işin yapılacağına dair söz verilmiş olur. Bu bağlamda "söz vermek" veya "vaatte bulunmak" demek, aynı zamanda "ant içmek / vermek” demektir. Onun için "ant” kavramının Türkçedeki kökenine ve tanımına kısaca göz atmak faydalı olacaktır.

Türkçede "ant” sözcüğünün kökenine dair yapılan bir araştırmada onun ilk şeklinin Eski Türkçedeki "and”' olduğu (Ünal, 2013: 225) belirtilmiştir. Tarih boyunca Türklerin farklı medeniyetlerle ilişkisinden ötürü, bu kavram Türkçede farklı kelimelerle de ifade edilmiştir. Türkçe "ant" sözcüğü, mesela "kasam", "sûkend" (Alptekin, 2009: 24), "yemin", "ahit" (Yarcı, 2013: 24) vb. gibi yabancı menşeli kelimelerle karşılanmıştır. Arapçadaki yemin sözcügüyle aynı anlama gelen "ant” kelimesinin "Türkçe Sözlük”teki tanımı şu şekilde verilmiştir: "1. Tanrı'yı veya kutsal bilinen bir kişiyi, bir şeyi tanık göstererek bir olayı doğrulama, yemin. 2. Kendi kendine söz verme, ahit" (Komisyon, 2005: 104). "Ant içmek” ise şöyle tarif edilmiştir: "Bir şeyi yapmaya veya yapmamaya söz vermek, yemin etmek" (Komisyon, 2005: 104). Yapılan tariflerden de görüleceği üzere kelime kutsallık temeline oturtulduğu için, söz konusu olguya sonradan belli geleneksel törenlerin eşlik etmesi gayet mantıklı görünmektedir. 
"Ant" müessesesinin insanlık tarihinde ortaya çıkışını tam olarak tespit etmek mümkün değilse de kadim dönemlere uzandığ ifade edilebilir. Bu hadiseden mütevellit ortaya çıkan ve söze hareketlerin eşlik ettiği "ant içme" eyleminin de yine çok eski bir geçmişi olsa gerektir. Nitekim bir araştırmacı, anda ait geliştirilmiş formüllerin, resmi kayıtlarda milattan önceki yüzyıllara kadar uzandığını söylemektedir (Gökdemir, 2003: 63). Bu kapsamda bütün dinlerde "ant” müessesesine rastlandığ1 bilinmektedir. Mesela, konuyla ilgili olarak Kuran'da "Mâîde” suresinin 89. ayetinde şu ifadeler yer alır:

Allah kasıtsız olarak ăgzınızdan çıkan yeminlerinizden dolayı sizi sorumlu tutmaz.

Fakat bilerek yaptığınız yeminlerden dolayı sorumlu tutar. Bunun da kefareti, ailenize yedirdiğiniz yemeği orta hallisinden on fakire yedirmek yahut onlart giydirmek yahut da köle azat etmektir (Bilmen, yty: 817).

Ayette de görüldüğü üzere yemin (ant), "verilmiş söz/söz verme” anlamına gelmektedir. Bugün de gündelik yaşantıda sıklıkla karşımıza çıkan “ant içme” olgusu, esas itibarıyla yazılı kuralların bulunmadığı veya gerekmediği zamanlarda kişi, kişiler, toplumlar gibi ister ferdi ister toplu yapılan anlaşmaları kutsal bir zemine oturtmak için ortaya çıkan sözlü bir senettir. Nitekim bir araştırmacı dilimizde de yer etmiş şekliyle bu terimin Arapçası hakkında şu tanımı yapmıştır:

Yemin kişinin bir şeyi yapacă̆ına veya yapmayacağına dair kutsal bilinen şeyler ve namus kavramlarl üzerine söz vermesi ve kesin güvence vermesi, yemin sözleri de bu söz ve güvence için kullandı̆̆ sözlerdir (Aydın, 2009: 24).

Zira insanoğlu yaratılışı gereği hem güven hem güvensizlik duygularına sahip olan bir varlıktır. Onun için insan güven duymak için söz alır ve söz verir.

Birine söz vermeye veya birinden söz almaya zamanla fiziksel hareketlerin eşlik ettiği ve neticede bu eylemin komplike bir törene dönüştüğü anlaşılmaktadır. Bu olgu, özellikle, sözlü kanunlar olarak addedilen örf ve âdetlerin yaşatıldığı gelenekçi toplumlarda kendini daha fazla muhafaza etmiştir. Bu kapsamda geleneksel yaşamın yansıdığı ve içinde örf ile âdetlerin korunduğu önemli metinlerden biri destanlardır. Geleneksel hayatın önemli hadiselerinden biri olan "ant içme" eylemi de bu çerçevede Türk destanlarına yoğun şekilde yansımıştır. Edebî eserlere yansıyan olgular ise gerçek hayatta karşımıza çıkan olaylarla sıkı ilişki içindedir. Onun için edebî eserlerdeki olgular, tarihî olaylardan bağımsız olarak düşünülüp değerlendirilemez. Türk destanlarında "ant içme" törenine dair örnekleri incelemeden evvel tarihî süreçte Türklerde "ant içme” geleneğine dair kısa bilgi vermekte fayda vardır.

\section{Türklerde geleneksel "ant içme" müessesine kısa bir bakış}

Çeşitli milletlerde hem sosyal ve kültürel hem de siyasî hayatın bir parçası olarak ortaya çıkan ve günümüze kadar gelen "ant içme" töreni Türkler arasında da çok eski dönemlere gitmektedir. Bu bağlamda Ural-Altay kavimleri arasında gösterilen İskitlerden Hunlara, Göktürklerden Uygurlara kadar birçok eski Türk devletinde bu geleneksel törene rastlanmıştır. İslam dinini kabulden sonra da geleneksel "ant” müessesesi Türkler arasında yaşamaya devam etmiş ve hatta Osmanlı Devleti'nde bu âdet son döneme kadar canlı bir şekilde yaşatılmıştır. 
Bugün de çağdaş Türkiye'de geleneksel "ant" müessesinin, mesela asker ve milletvekili antları gibi, çeşitli biçimlerde yaşatıldığı bilinmektedir.

Bu kapsamda tarihin en eski dönemlerine gidildiğinde İskitlerin kendi inanışları çerçevesinde "ant içme" geleneğini uyguladığı görülmektedir. Bu hususla ilgili bilgileri Herodotos şöyle aktarmaktadır:

Toprak bir kupanın içerisine şarap doldururlar; ant içecek olanlar buna kanlarını karıştırırlar; bunun için sivri bir şeyle küçük bir delik açarlar ya da kilıçla hafif çizerler; sonra kabın içerisine bir pala, oklar, bir balta ve mızrak daldırırlar. Bu da olduktan sonra ant içerler ve kaptaki şaraptan azıclk içerler ve orada bulunanların ileri gelenleri de onlarla beraber içerler (Herodotos, 1991'den Durmuş, 2009: 9899).

Geleneksel "ant içme" töreniyle ilgili en eski kayıtlardan biri de MÖ I. yüzyıla aittir ve Çin elçileri ile Hun hakanı Huhanye arasında yapılmıştır:

Çin elçileri Çan ve Mın, Hun hakanı Huhanye ve boy başbuğları, No-Şuy ırmağının doğusundaki Hun Dă̆ı'na çıktılar ve bir beyaz at kurban kestiler. Hakan seferlerde kullandı̆̆ı (en değerli) kılıcını eline alarak ucunu şaraba batırdı ve bu antlı şarabı Yüeçi hanının kafatasından yapılmış kapla içti (İnan, 1948: 279).

Milletler arası uzlaşmaya dayalı geleneksel "ant içme” törenleri de gerek Avarlar gerekse Göktürklerde (Durmuş, 2011: 101) karşılaşılan bir hadisedir. Yine, "ant içme” töreni kullanılmak suretiyle Uygurların Çinlilerle yaptığ

Göğün oğlu Tang uzun yıllar yaşasın. Aynı zamanda Uygur Kă̆anlığı da uzun yıllar yaşasın. İki devletin general ve bakanlarının şerefine içilsin. Her kim bu antlaşmayı bozarsa, onun ordusunun askerleri yok olsun ve onun bütün soyu sopu kurusun. Ant şarabı getirildiği zaman Uygur bakanları da şöyle söylediler: Biz senin andınla ant içeriz (Mackerras, 1968'den Durmuş, 2009: 105).

$\mathrm{Bu}$ bilgilerden görüleceği üzere, eski dönem Türk devletleri ile farklı milletler arasında "ant içme" töreni sosyal, siyasî, kültürel gibi değişik vesilelerle yapılmıştır. Bu törenlerde gerçekleştirilen "ant içme" ritüeli ise çok çeşitli şekillerde gerçekleştirilmiştir. Daha sonraki dönemlerde de bu hadiseyle ilgili benzeri geleneksel törenler olmuştur. Nitekim X. yüzyılın ilk yarısında eserini yazan İslam müelliflerinden İbn-ül Fakih Türklerin gelenek ve göreneklerinden bahsederken "ant" konusuna temas etmiştir (İnan, 1998: 318). Gene Abdulkadir İnan, Mahmut Kaşgarî’nin eserinden hareketle Kırgız, Yabaku, Kıpçak ve daha başka kabilelerin "ant” içtikleri zaman kılıcı çıkararak yanlama önlerine koyduğunu ve bunun "Gök girsin, kızıl çıksın” anlamına geldiğini belirtir (İnan, 1998: 319). Bu geleneğin Macarlarla Kumanlar arasındaki varlığına dair bilgiler de tespit edilmiştir (Aktaş, 2013: 3-4).

Türk kültüründe tarihî derinliği bulunan bu kültürel hadise orta dönem Müslüman Türk devletlerinde hem siyasal yaşamda devam etmiş hem de edebiyata yansımıştır. Nitekim Abdulkadir İnan Müslüman Türklerin arasında şer'i kaza makamlarının asırlardan beri fikhın kabul ettiği yemini tatbik ettiklerini, bununla beraber eski "ant” geleneklerinin, İslam Türklerin hayatında ve folklorunda derin izler bıraktığını ifade eder (İnan, 1998: 322). 
Örneğin Karamanoğlu II. İbrahim Bey, Osmanlı sultanı II. Murad'a yaptıklarından ötürü bir “Ahidnâme" (ant belgesi) vermiş (Aköz, 2005: 85) ve bu hadise tarihî kayıtlara geçmiştir. Yine Osmanlı padişahlarının kılıç kuşanırken yemin ettikleri ve ayrıca biat yeminleri yaptıkları ifade edilmiştir (Yarcı, 2013: 24-25). Aynı zamanda Osmanlı Devleti'nin hükümdarlarından II. Beyazıt'la I. Selim devri klasik Türk edebiyatı şairleri "kan yalaşıp dost olma” hususunu şiirlerinde işlemiş̧ler (Yazıksız, 1316'dan Durmuş, 2009: 102).

"Ant içme" töreninin günümüz Sibirya Türk toplulukları arasında eski Türk dinine uygun şekilde devam ettiği de belirtilmiştir. Mesela A. İnan, “ant” içecek Altaylıların ayı derisi üzerine oturup burun deliklerini öptüğünü ve ayının canilere ceza vereceğine inandığını yazmaktadır. Keza, Yenisey nehrinin kaynaklarında yaşayan Salcakların yemin ederken "gün, ay görüyor" diyerek tüfek namlusunu yahut bıçak yüzünü yaladığını, sonra ise ayı kafası bulunan kaptan su içip "Bu suyu içtiğim gibi ayı beni yesin" diyerek yemin ettiğini dile getirir. Aynı yazar, Yakutların da ant töreninde kılıç yahut tüfek gibi silahları öpmek âdetlerini uyguladığını, Buretlerin ise süngünün ucunu öptüğünü ifade eder (İnan, 1998: 320).

\section{Türk destanlarında "ant içme" ritüeli}

Peki, tarihin kadim dönemlerinden günümüze kadar Türklerin yaşamında çeşitli biçimlerde uygulanan "ant içme" töreni Türk destanlarına da yansımış mıdır? Bu soruya verilecek cevap evettir zira bilindiği üzere hemen tüm milletlerin destanları temelde siyasî, tarihî ve kültürel olaylara dayalı anlatılardır. Elbette, bu olaylar çeşitli unsurlarla süslenmiş, içlerine efsane, mit, menkıbe gibi başka hikâyeler katılmış ve hatta bağlantılı olmayan birçok olağanüstü hadise de bu vakalara eklenmiştir. Tarihî vakaların çeşitli unsurlarla beslenerek genişlemesi sonucu ise "destan" türü ortaya çıkmıştır. Bu bağlamda kültürel, sosyal veya siyasal yaşamın bir parçası olan "ant içme" töreni çok mebzul biçimde ve değişik şekillerde Türk destanlarına yansımıştır.

Oysa "Manas" ve "Dede Korkut" gibi bir iki metin haricinde Türk destanlarındaki "ant içme" töreni üzerine şimdiye kadar hiç araştırma yapılmamıştır. Buna göre konuyla ilgili ilk araştırmalardan biri Abdulkadir İnan'a ait olup o, genel anlamda "ant” hadisesini ele alsa da "Kitab-1 Dedem Korkut", "Manas” gibi metinlerden hareketle bunun örneklerini incelemiştir (İnan, 1998: 317-330). Konuya ilişkin Özlem Deniz tarafından kaleme alınan bildiride ise sadece “Manas Destanı” ele alınmıştır (Deniz, 1995: 256-268). Ali Berat Alptekin ise yazdığı makalede yeminin halk hikâyeleri (Kirmanşah, Şah İsmail vb.), masallar (Taşeli, Ardanuç vb.) ve bazı destanlarda (Kitab-1 Dedem Korkut, Manas, Köroğlu vb.) yansıma şekillerini irdelemiştir (Alptekin, 2009: 23-33). Kısaca bu araştırmalarda "ant içme" hadisesi birkaç bilindik destandan hareketle ortaya konulmuş, özellikle de "Manas Destanı" ile "Kitab-1 Dedem Korkut" eseri ön plana çıkarılmıştır. Hakikaten bu iki destan metni Türk dünyası destanları içerisinde mühim bir yer işgal etmektedir. Onun için bunların temelinde yapılan araştırmalar da önem arz etmektedir.

Bundan mütevellit konuya ilişkin olarak bu eserlerdeki birer örneği paylaşalım. Mesela "Kitab-1 Dedem Korkut” eserinin Salur Kazan Oğlu Uruz Beyin Tutsak Olduğu Boy adlı hikâyede Salur Kazan, beyleriyle birlikte otağında otururken sağına bakıp güler, soluna bakıp 
güler, karşısında duran oğlu Uruz'u görünce ağlar. Uruz, bundan müteessir olur ve babasına bunun sebebini açıklamazsa Oğuz ilinden ayrılacağına, kâfir eline gidip Hıristiyan olacağına ant içer (Ergin, 1997: 154, 155). W. Radloff'un derlediği “Manas Destanı"ndaki kahramanlar ise İslam öncesi uygulamalarla "ant içme" törenini yerine getirir. Mesela alplar, taş ve su ile ant içerler. Yalan yere ant içerlerse su kurur, taş yarılır (İnan, 1998: 143).

Mezkûr araştırmalar haricinde "ant/yemin” konusunu inceleyen başka çalışmalar vardır. $\mathrm{Bu}$ araştırmalarda bazı destanlardan, özellikle Dede Korkut’tan, örneklere yer verilmiştir. Ancak bu tarz çalışmalarda destan metinleri araştırmanın merkezinde değildir. Onun için bu makalede, bir başlangıç olarak, Türk dünyasından yirmi destan metni ele alınacak ve bunlarda yer alan "ant içme" ritüelinin çeşitleri üzerinde durulacaktır. Bu bağlamda makalede Oğuz, Kırgız, Kazak, Tatar, Başkurt, Karakalpak, Nogay vb. gibi pek çok Türk boyunun destanları incelenecektir.

Şimdiyse "ant içme" töreninin Türk destanlarındaki zenginliğini ortaya koymak açısından yukarıda ifade edilen destan metinlerine göz atmakta ve bunları işlevleri bakımından bir tasnife tabi tutmakta fayda vardır. Bu bağlamda incelediğimiz destan metinleri göz önünde bulundurulduğunda "ant içme" hadisesi Türk destanlarında işlevsel açıdan iki ana başlık altında tasnif edilebilir. Türk destanlarında "ant içme”nin ilk işlevi sadece söze dayalı "söz verme" şeklindedir. "Ant içme”nin ikinci işlevi ise verilen söze çeşitli fiziksel hareketlerin eşlik etmesidir. Buna göre Türk destanlarındaki bu olgu aşağıda yer alan başlıklar altında değerlendirilebilir:

1) "Sözden ibaret ant içmeler"

2) "Söz ve hareketten oluşan komplike ant içmeler"

\subsection{Sadece yemin, söz vb. ifadelerin kullanıldığı sözden ibaret ant içmeler}

Türk destanlarında sadece sözden ibaret olan antlar, esas itibarıyla bir şarta veya koşula bağlı olarak yapılan pazarlıkları, gerçekleşmesi muhtemel bir durumdan ötürü geleceğe dair vaatleri ve karşılıklı görüşmeler neticesi uzlaşmaya dayalı anlaşmaları ifade etmektedir. $\mathrm{Bu}$ tür antların ortak özelliği ise temelde söze dayalı yemin ifadeleri kullanmak ve ayrıca herhangi bir durumdan ötürü verdiği sözü yerine getireceğine dair bir isteği dile getirmektir. Onun için dil ile ifade edilen bu yemin tarzını sözlü antlar veya basit antlar olarak da isimlendirmek mümkündür. Zira bunlara herhangi bir fiziksel eylem eşlik etmez ve bunlar yalnızca sözden ibaret olurlar. Bu yüzden sözlü antlar yerine getirilmeyebilir, hatta bunlardan vazgeçilebilir.

Türk destanlarında bu tarz antlara sıklıkla rastlanmaktadır. Mesela sözlü antlara dâhil edebileceğimiz geleceğe dair vaatlerin biri Kırgızların "Canıl Mırza Destanı”nda görülmektedir. Canıl Mırza, Kalmatay'dan buyruk vermese, dışarı çıkınca kendini aramasa ve unuttuğu bir buyruğu sürekli hatırlatmasa onunla evliliğe razı olacağını söyler (Caynakova, 2004: 71). Kalmatay ilkin bu şartları kabul eder ancak daha sonra verdiği sözleri tutmaz ve Canıl Mırza'yı dövmeye, ona sövmeye ve buyruk vermeye başlar (Caynakova, 2004: 73). Görüldüğü üzere söze dayalı ant içmeler destanda tavsif edilen toplumda çok ciddi olarak düşünülmemiştir. Buna göre sözden ibaret antları işlevsel açıdan değerlendirince onun üç alt başlığa ayrıldığı görülmektedir. 


\subsubsection{Geleceğe dair vaatlerden oluşan antlar}

Geleceğe dair vaatleri sözlü antların bir türü olarak değerlendirmek yanlış olmayacaktır zira vaatler de bir tür söz vermedir, dolayısıyla söz düzeyinde bir "ant içme" çeşididir. $\mathrm{Bu}$ husus, özellikle çocuksuz padişahlar ile vezirlerin dileklerinin gerçekleşmesi hâlinde çocuklarını evlendirmek için birbirine söz vermeleri şeklinde görülür. Gerek destanlarda gerekse halk hikâyelerinde pek sık rastlanan bu durum genelde babanın, kızını karşı tarafa vermemek için inat etmesinden ötürü çoğu zaman mutsuz sonla bitmektedir.

Örneğin Tatarların "Kuzı Kürpeç Bilen Bayansılu Destanı”nda Ak Han ile Kara Han'ın eşleri hamile olur. İki han, çocuklarının biri kız diğerinin erkek olması hâlinde onları evlendirmeye ant içerler (Urmançı, 2007b: 31). Türk dünyasında en yaygın destanî metinlerden biri olan bu destanın Başkurtlardaki varyantında da aynı şekilde böyle bir vaat bulunmaktadır. Başkurtların “Kuzıykürpes Destanı”nda Sarıbay, Karabay’a kızını verdiğini söyler ve ikisi herkesin önünde el sıkışıp anlaşırlar (Ergun-Gaynislam, 2000: 385).

$\mathrm{Bu}$ "ant içme" motifinin aynısı pek çok destan ve hikâyede karşımıza çıkar. Örneğin bu motif, "Kitab-1 Dedem Korkut”un Kam Püre Beg Ŏglu Bamsı Beyrek Boyunda (Ergin, 1997: 117) ve "Kerem ile Aslı Hikâyesi”nde (Elçin, 2000: 20) de görülmektedir. Başka bir Tatar destanı olan "Şahsenem Hem Garip”te de padişah ve veziri hamile hanımlarının doğurdukları çocukları birbirine vermek için vaatte bulunurlar (Urmançı, 2007b: 263). Elbette, bunlar, sıradan antlar olarak gerçekleştirilmenin yanı sıra törensel biçimde de yapılabilmektedir. Nitekim Kam Püre Beg Oğlu Bamsı Beyrek Boyunda bu hadise komplike hâle dönüşmüş ve "ant içme" sadece söz vermekten ibaret kalmamıştır. Beşik kertme denilen fiziksel hareket de bu anda eşlik etmiştir.

\subsubsection{Pazarlıklara dayalı antlar}

Pazarlık yapmak suretiyle verilen sözler de sözlü antların bir çeşididir. Örneğin Kırgızların “Kococaş Destanı”nda Sur Eçki, Kococaş'la pazarlık yapmak ister ve "Ver kocamı al hayır duamı!” der, fakat kahraman buna yanaşmaz (Akmataliyev-Kırbaşev, 2007: 111). Gene Tatarların “Edigey Destanı"nda Edigey, Akbilek'e onu kurtarırsa babasının kendisine ne vereceğini sorar. Akbilek babasının, kendisini ve istediği her şeyi ona vereceğini söyler (Sulti, 1998: 91). Kazakların "Dotan Batır Destanı”nda da Şıntemirhan düşmanı yenmesi hâlinde Dotan'a kızını vereceğini söyler. Şıntemir Han, kızını Dotan'a verdiği için pişman olup sözünden caymak ister ve ona yarışmada kimin atı birinci gelirse kızı onun alacağı haberini gönderir (Arıkan, 2007: 277, 291). Neticede Şıntemir Han, anlaşmaya uymaz ve güreş, yaya, nişan vurma yarışlarının olduğunu söyler (Arıkan, 2007: 293, 295, 297).

Türk destanlarında bu antların başka örnekleri de mevcuttur. Filhakika Kırgızların “Er Töştük Destanı”nda Celmogus, Eleman'ı Töştük’ü vermek koşuluyla serbest bırakır (Turgunbayev, 1996: 128). Kırgızların “Munduk ve Zarlık Destanı”nda Mastan, hanın altmış hanımına her biri altmış tabak dolusu altın verirse Kançayım’ın çocuğunu yok edeceğini söyler (Akmataliyev-Mukasov-Orozova, 2007: 203). Yine Kazakların “Kozı Körpeş Bayan Suluv Destanı”nda Kozı'nın karşılaştı̆̆ı Karabay’ın çobanı Keloğlan, yüz koyun alıp gitmek koşuluyla Kozı'yla anlaşır ve yerini Karabay’a söylememesini ister (Kuanışbayev, 2000: 63). Bütün bu örneklerdeki pazarlıklarda görüleceği üzere bariz bir alışveriş söz konusudur. 
Esas itibarıyla bu örnekleri çoğaltmak mümkündür zira pazarlığa dayalı bu "al-ver" motifi ve buna bağlı antlar Türk destanlarında pek fazladır. Lakin özellikle "Dotan Batır Destanı"ndaki temanın Türk dünyası destanlarında yoğun işlendiğini ve verilen sözden cayma motifinin de bu metinlerde önemli bir yer işgal ettiğini ifade etmek gerekir. Nitekim benzeri motif yazılı ilk başat eserlerimizden olan "Kitab-1 Dedem Korkut”un Kanlı Koca Oğlu Kan Turalı Boyunda da geçmektedir (Ergin, 1997: 193). Ancak bazı pazarlıklarda kimi kolaylıklar elde etmek ya da daha iyi bir çözüme varmak için yapılan görüşmeler de yapılabilmektedir. Mesela Kazakların “Karasay-Kazı Destanı”nda genç bir kadın Kazı'ya eğer isteğini gerçekleştirirse ona Adilhan’ın kapatıldığı yeri göstereceğini söyler (Serginbayev, 2007: 325). Bu örnekte ise bir alışverişten ziyade mevcut bir problemin çözümü söz konusudur.

\subsubsection{Yapılan anlaşmaların temelinde antlar}

Anlaşmaya yani uzlaşıya dair karşılıklı görüşmeler de sözlü antların bir türüdür. Nitekim Türk destanlarında anlaşmaya dayalı söz vermeye de sıklıkla rastlanmaktadır. Örneğin Başkurtlara ait “Alpamışa Destanı”nda kahraman (Alpamışa), atı Kızılsarı'yı kendilerine ihanet eden çobanından (Koltaba) almak için ona yılkı ve sığır sürülerini teklif eder. Koltaba bunu kabul etmez fakat Alpamışa ona kız kardeşiyle annesini vermeyi teklif edince çoban bunu kabul eder (Ergun-Gaynislam, 2000: 252).

Anlaşmaya dayalı sözlü antlar da her zaman yerine getirilmeyebilir. $\mathrm{Bu}$, sadece kahramanın rakibini alt etmek için kullandığı bir yöntemdir. Nitekim Alpamışa, anlaşma esnasında Koltaba'nın elini o kadar sıkar ki Koltaba ondan istediği tüm şeyleri geri vermek zorunda kalır (Ergun-Gaynislam, 2000: 253). Neticede Alpamışa, hain çoban Koltaba’yı hem kurnazlık ederek hem de acı kuvvetini kullanarak verdiği sözden caydırmış ve böylece anlaşma da bozulmuş olur.

Kırgızlara ait "Er Eşim Destanı”nda da anlaşmaya ihanet eden dost motifi karşımıza çıkar. Filhakika destan kahramanı Er Eşim, halkını Han Tursun'a bırakır ve halkına bakması için onunla anlaşma yapar (Akmataliyev-Mukasov-Orozova, 2007: 75). Ancak Han Tursun bu andını unutup, Er Eşim'in ailesi ve halkına zulmeder (Arvas, 2012: 195). Başka bir Türk topluluğu olan Nogayların "Mamay Destanı”nda da Mamay, atlarının arsasına girdiği yaşıı adama gidip onunla anlaşma yapar. Mamay, kardeşi Orak'1 atlarına bakması için ona vermeyi ve onun da Orak'a bakmasını teklif eder (Kalenderoğlu, 2001: 187). Burada da anlaşma temelinde söz verildiği yani ant içildiği ancak bu andın yerine getirilmediği görülmektedir (Arvas, 2012: 196).

\subsection{Yemin vb. sözlere hareketlerin eşlik ettiği komplike ant içmeler}

Belli fiziksel kaidelere bağlanarak uygulanan "ant içme"ler hem komplike hem törensel bir karakter arz etmekte ve daha ciddi bir durumu ifade etmektedir. Bu tarz törensel antlar çok çeşitli biçimlerde görülmektedir. Örneğin değişik nesneler üzerine yapılan "ant içme”ler verilen söze fiziksel bir eylemin eşlik etmesini gerektirmektedir ve genelde bu nesne ya kutsaldır ya da tarihî derinlikte bir kutsallık arz etmektedir. Sonradan bu kutsallığın sebebi unutulsa da içtimai zihniyette derin etki bırakmasından ötürü bu durum toplum içinde 
yaşamaya devam eder. Bu tür "ant içme" tarzına Türklerin hem İslam öncesi hem de İslam sonrası dönemlerinde rastlamak mümkündür.

Üstelik farklı iki dönemde vuku bulan "ant” tarzları da gerek münferit gerekse müşterek şekilde kullanılmak suretiyle kendini destanlarda korumuştur. Mesela Kırgızların "Kurmanbek Destanı"nda Kurmanbek ve Akhan, Kuran'a el basıp ekmek yiyerek ant içerler (Arvas, 2012: 193). Burada Müslüman olan Kırgızların İslam dininin kutsal kitabı Kuran’a karşı kuvvetli bir inancı dile getirilmektedir. Ekmek ise burada belki İslami belki de çok daha eski bir gelenek olmak suretiyle nimet olarak değerlendirilebilir. Eğer ekmek İslami gelenekten ötürü destana yansımışsa bunda garipsenecek bir durum yoktur zira bu, Müslüman bir toplumda gayet anlaşılır ve karşılığı olan bir hadisedir.

Ancak ekmeğin nimet haricinde daha derinlere giden başka bir işlevsel anlamının olması da ihtimal dâhilindedir. Nitekim Kırgızların “Seytek Destanı”nda Ayçürök ile Kuyalı keskin kılıcı yalayarak ve akbuğdaydan yapılmış ekmeği çiğneyerek dost kalacaklarına dair yemin ederler (Gölgeci, 1995: 75). Burada ise ekmek, İslam sonrası değil İslam öncesi dinî hayatın pratiğini içinde barındırmaktadır. Belki de bu kompleks ve ritüelistik antta karşımıza ekmek unsuru insanlık tarihinde tarım devrimi (Harari, 2012: 89) denilen döneme kadar uzanmaktadır. Bu anlamda, komplike "ant içme" tarzlarının hem İslami hem de eski Türk dini unsurlarını barındıran çok farklı şekilleri olduğunu ifade etmek mümkündür.

\subsubsection{Demir kültüne uzanan antlar}

Komplike "ant içme" ritlerinde karşımıza çıkan en ilginç ve en eski türlerden biri kılıç temelinde yapılan antlardır. Kılıç, bıçak, nacak vb. gibi malzemesi demirden olan nesnelere karşı beslenen saygı veya korkunun bu araçların kesme özelliğine dayandığı ve dolayısıyla demir kültüne uzandığı bilinmektedir. Zira demir madeninin keşfi neticesinde demirden yapılan nesneler insanlık tarihinin önemli gelişim aşamalarından birini teşkil etmiştir. İşte bu mühim hadise insanların bilincinde kök salmış ve çok sonraki dönemde icra ettikleri destan metinlerine de yansımıştır. Bu bağlamda Türk destanlarının çoğunda kılıç üzerine, kılıca dayalı veya kılıç temelinde yapılan antlarla sık sık karşılaşılmaktadır. Örneğin "Seytek Destanı”nda Kıyaz, Kançoro’ya Külçoro’yu öldürmeyip onunla dost olmayı ve kılıcı yalayıp “ant içme"yi teklif eder (Subaşı, 1995: 52).

Kılıç üzerine "ant içme”ler, sadece kılıç “yalama” eylemi ile değil aynı zamanda kılıçları "birbirine sürtme" ve kılıçla "kesme" gibi farklı şekillerde de yapılabilmektedir. Nitekim “Canıl Mırza Destanı”nda Akkoçkor, adamlarıyla beraber kılıcın keskin tarafını yalayıp Canıl'a acımayacaklarına dair ant içerlerken (Caynakova, 2004: 39); kardeşi Kankı ile ise kılıçlarını birbirine sürtüp ant içerler (Caynakova, 2004: 138). Kimi zaman kılıçla yapılan antlar esnasında kılıca başka nesneler de eşlik eder. Mesela Kırgızların “Er Eşim Destanı”nda Er Eşim ve Kataganların hanı Han Tursun, hem kılıcın yüzünü yalayarak hem de tüfeğin namlusunu öperek ant içerler (Akmataliyev-Mukasov-Orozova, 2007: 71).

İşte bu "ant içme" ritleri Türklerin İslam dinine girmeden çok önce kutsal saydıkları demire karşı olan saygıdan ötürü ortaya çıkmış ve etrafında belli ritüelistik gelenekler oluşturmuştur. Bu durum, içtimai bilinçaltına yerleştiğinden ötürü Müslüman olduktan sonra 
da devam etmiş ve neticede destanlara yansımıştır. Kırgızların "Semetey Destanı”nda kılıcın yanı sıra ok da "ant içmek" üzere kullanılan bir araç olarak geçmektedir. Nitekim İsmail, ablası Kanıkey'in oğlu yani yeğeni Semetey’e oğlu gibi bakacağına dair kılıcı yalamak ve oku kavramak suretiyle yemin eder (Koç, 1998: 75). Bu örnekte yer alan okun keskin bir alet olduğu ve bir kısım malzemesinin demirden yapıldığı düşünüldüğünde kılıç temelinde ortaya çıkan antların demir kültüne dayandığı daha anlamlı hâle gelecektir.

\subsubsection{A ğaç kültünden kaynaklı antlar}

İnsanoğlu binlerce yıllık yeryüzü serüveninde doğadaki pek çok nesneyi keşfetmeye, anlamaya, kullanmaya ve korumaya çalışmıştır. Bu yüzden de insanlık tarihi boyunca her kabile ve millet çeşitli kültler geliştirmiştir, denebilir. Bu kapsamda tarihin derinliklerine uzanan ve insanlığın hafızasında çok keskin şekilde yer edinen bir kült de ağaçtır. Kısacası, Türklerde İslam öncesi döneme uzanan ve demir kültüne benzer olan bir gelenek de ağaç kültüne dayalı "ant içme” ritüelidir. Bu tarz ritüelleri çeşitli Türk destanlarında görmek mümkündür.

Nitekim “Seytek Destanı”nda Kançoro ve Kıyaz söğüt dalı kopararak ant içerler (Subaşı, 1995: 71). Bu külte dayalı bir örneği de "Kitab-ı Dedem Korkut"un Salur Kazanın Evinin Yağmalandığı Boyda görmekteyiz. Bu hikâyede Uruz, kâfir tarafından dar ağacına götürüldüğünde ağaçla söyleşir ve dar ağacından kendisini asmamasını çeşitli örnekler (Mekke ile Medine'nin kapısı ağaç, Musa Kelim'in asası ağaç, Hasan ile Hüseyin'in beşiği ağaç, vb. gibi) üzerinden dile getirir (Ergin, 1997: 108-109).

$\mathrm{Bu}$ tür antların, insanlar üzerindeki psikolojik etkisi çok yüksek olduğu için genelde yerine getirilmektedir. Yine de, nadir olsa bile, ritüelistik antların uygulanmadığg durumlar olabilmektedir. Nitekim Başkurtların “Akhak Kola Destanı”nda bunun bir örneği bulunmaktadır. Akhak Kola'nın sahibi yer kazıp yemin ettiği hâlde yeminini bozar (ErgunGaynislam, 2000: 185). Görüldüğü üzere burada sadece söz değil, törensel bir eylem de vardır. Bu destandaki "yer kazma” ise "Kitab-1 Dedem Korkut”tun farklı boylarında karşımıza çok sık çıkan "yer kertme" andını akla getirmektedir.

\subsubsection{Sözün gücüne (büyüsüne) olan inançtan doğan antlar (Kargışlı antlar)}

Bazen sadece sözden ibaret olduğu hâlde kompleks mahiyetindeki antlarla da karşılaşmak mümkündür. Burada her ne kadar sadece söz varsa da bu söz sıradan değil, büyülüdür. Onun için de insan psikolojisi üzerinde çok etkilidir. Hatta bazı sözlü antlar bu anlamda komplike antlardan bile daha etkileyici olabilir. Zira buna olan inanç çok kuvvetlidir ve sözün yerine getirilmemesi durumunda çeşitli felaketlere uğranacağı düşünülmektedir. Bunun en güzel örneği ise kargışlı antlardır, denebilir. Çünkü kargışta eylem olmasa da verilen söz sıkı bir sebebe bağlanmaktadır.

Mesela; "Semetey Destanı”nda Semetey, Sarı Amca’sına “Söylediklerin doğruysa seni han yaparım, yapmazsam tepesi açık gök, dibi tüylü yer beni cezalandırsın ve Talas adı, Manas'ın ruhu beni çarpsın!” der (Koç, 1998: 149). Semetey, burada amcasına bir söz vermekte ve bunu da çok kuvvetli bir inanca bağlamak suretiyle kendini psikolojik açıdan tehlikeye atmaktadır. Kargışlı ant dikkatle incelenirse gök ve yer ruhlarına (tepesi açık gök, dibi tüylü 
yer, Talas) dair bilgilerin olduğu ve bunların da İslam öncesi dönemden kaldığg görülecektir. Kargışta aynı zamanda atalar kültünün de yer aldığı ifade edilebilir. Zira Manas'ın ruhu temelde ataların ruhlarının fayda veya zarar verdiğine dair inanışa dayanmaktadır.

$\mathrm{Bu}$ bağlamda antların kargışlarla sıkı bir ilişkisi olduğu söylenebilir. Bu tür antlar da Türk destanlarında yoğun şekilde işlenmiştir. Bu da Türklerin hangi inanç veya din olursa olsun mensubu olduğu inanca samimi biçimde bağlandığının göstergesi olsa gerektir. Buna benzer antlar "Kitab-1 Dedem Korkut”ta da sıklıkla geçer. Örneğin Uşun Koca Oğlu Segrek Boyunda Segrek karısına, kardeşi Egrek'i kurtarmadan döşeğe girerse "Kılıcıma doğranayım, okuma sançılanayım” şeklinde kargışlı bir ant içer (Ergin, 1997: 228). Aynı kargışlı ant diğer boylarda, mesela Kanlı Koca Oğlu Kan Turalı Boyunda (Ergin, 1997: 193) da geçer. Kargışa dayalı bu ant çeşidinin de kılıç ve ok gibi unsurlardan hareketle demir kültüne, yani İslam öncesi döneme bir gönderme yaptığı görülmektedir. Yer kazmak ise tarım döneminde toprağın kullanıma sunulmasına ve ürün vermesine bir gönderme olarak düşünülebilir.

\section{Sonuç}

$\mathrm{Bu}$ araştırmanın neticesinde elde edilen sonuçlar kısaca şöyle özetlenebilir: Türk destanlarına yansıyan "ant içme" hadisesi ve törenlerinin gerçek hayatın bir aksülameli olduğu ve yaşanan hadiselerin tıpkı yazılı edebiyatta olduğu gibi sözlü edebiyata da yansıdığı görülmektedir. Bu bağlamda edebiyatın gerçek hayattan bağımsız olmadığı ve sözlü edebiyatın parçası olan destanların ise yaşanan kültürel hadiseleri gerçekçi bir şekilde yansıttığı anlaşılmaktadır. Destanlarda çok renkli biçimde aktarılan "ant içme" töreninin gerçek hayatta var olduğunu tarihî veriler de doğrulamaktadır. Nitekim bu amaçla, makalede Türk kültürel ve siyasal hayatında var olan örneklere değinilmiş ve bunların destanlardaki örneklerle örtüştüğü görülmüştür.

Türkler, çevresindeki medeniyetlerle iletişime geçtiği dönemlerden itibaren doğal olarak hem onları etkilemiş hem de onlardan etkilenmiştir. Bunun neticesinde ise kültürel ve inanışlar bakımından bu medeniyetlerden çeşitli unsurları ödünç almış ve zamanla da benimsemiştir. Bu kapsamda özellikle İslam sonrası dönemde Kuran-1 Kerim üzerine "ant içme" bunun çok bariz bir örneğidir. Buna karşın, kendi yaşam tarzları ve kültürel birikimleri sonucu ortaya koydukları birçok "ant" biçimi de mevcut olmuştur.

Bu bağlamda da, mesela kılıç üzerine yapılan “ant” çeşitleri, dost olmak için kan yalaşarak edilen yeminler eski Türk geleneklerinden mütevellittir, denebilir. İşte gerçek yaşamda uygulanan bu pratiklerin de, özellikle millî kültüre dayalı olan "ant içme" ritüellerinin, Türk destanlarında yoğun biçimde işlendiği görülmektedir. Bu araştırmada ayrıca şu sonuca da varılmıştır: Türk kültüründe, tarihinde, sosyal yaşamında tarihsel dönemlerden bugüne değin yaşayan "ant” müessesesi tarihî ve edebî metinler olan destanlara yansımıştır.

\section{Notlar}

1 Bu konuya ilişkin detaylı bilgi için bk. (Ünal 2013).

2 Klasik Türk şiirinde "ant içme” olgusu pek çok şairden alınan örneklerle ortaya konmuştur (bk. Nas 2017). 


\section{Kaynaklar}

Akmataliyev, A. ve Kırbaşev, K. (2007). Kırgız destanları 3. (F. Türkmen, G. Uzun ve B. B. Hança Çev.). Ankara: Türk Dil Kurumu.

Akmataliyev, A., Mukasov, M. ve Orozova, G. (2007). Kırgız destanları 2. (C. Turgunbayev, Çev.). Ankara: Türk Dil Kurumu.

Aköz, A. (2005). Karamanoğlu II. İbrahim Bey’in Osmanlı Sultanı II. Murad'a vermiş olduğu ahidnâme. Ankara Üniversitesi Dil ve Tarih-Coğrafya Fakültesi Dergisi. S.24/38, ss. 71-92.

Aktaş, E. (2013). Türklerde ve Macarlarda ant içme ve kan kardeşliği. Acta Turcica. S. 2, ss.1-5.

Alptekin, A. B. (2009). Osmaniye örneğinden hareketle Batı Türkleri (Azerbaycan-Türkiye) destan ve hikâyelerinde ant (yemin) lar. Millî Folklor. S. 84, ss. 23-33.

Arıkan, M. (2007). Kazak destanları 2. Ankara: Türk Dil Kurumu.

Arvas, A. (2012). Kitab-ı Dedem Korkut ve Kıpçak sahası epik destan geleneği. Ankara: Hâkim.

Aydın, S. (2009). Yeminler. Halk bilimi sözlü anlatımlar içinde (24). Ankara: Kültür ve Turizm Bakanlığı Türkiye kültür portalı projesi.

Bilmen, Ö. N. (yty). Kur'an-ı Kerim'in Türkçe meâli âlisi ve tefsiri. İstanbul: Bilmen.

Caynakova, A. (2004). Canıl Mırza. ( M. Aça, Çev. ). Ankara: Türk Dil Kurumu.

Deniz, Ö. (1995). Manas ve Seytek destanlarında ant içme şekilleri. Bozkırdan bağımsızlı̆̆a Manas. (

E. G. Naskali Haz. ). (ss.256-268). Ankara: Türk Dil Kurumu.

Durmuş, İ. (2009). Türk kültür çevresinde ant. Milli Folklor. S. 84, ss. 97-106.

Durmuş, İ. (2011). Türklerde kan kardeşliği ve antla ilgili unsurlar. Milli Folklor, S. 89, ss. 100-108.

Elçin, Ş. (2000). Kerem ile Aslı hikâyesi. Ankara: Akçağ.

Ergun, M. ve İbrahimov, G. (2000). Başkurt halk destanları. Ankara: TÜRKSOY.

Gökdemir, G. (2003). Türk mitolojisinde yemin-ant müessesesi. Millî Folklor, S. 59, ss. 60- 72.

Gölgeci, M. (1995). Seytek/Külçoro'nun Semetey'e rastlaması (giriş-metin-aktarı-dizin). (Yayımlanmamış Yüksek Lisans Tezi), Marmara Üniversitesi Türkiyat Araştırmaları Enstitüsü, İstanbul.

Harari, Y. N. (2015). Sapiens insan türünün kısa bir tarihi. (10. bs). (E. Genç, Çev.). İstanbul: Kolektif. İnan, A. (1948). Eski Türklerde ve folklorda ant. Ankara Üniversitesi Dil ve Tarih-Coğrafya Fakültesi Dergisi. S. VI/4, ss. 279-290.

İnan, A. (1987). Eski Türklerde ve folklorda ant. Makaleler ve incelemeler. (ss.317- 330). Ankara: Türk Tarih Kurumu.

Kalenderoğlu, İ. (2001). Nogay Türklerinin “Mamay destanı”. (Yayımlanmamış Yüksek Lisans Tezi). Gazi Üniversitesi Sosyal Bilimler Enstitüsü, Ankara.

Koç, A. (1998). Semetey. (Yayımlanmamış Yüksek Lisans Tezi). Karadeniz Teknik Üniversitesi Sosyal Bilimler Enstitüsü, Trabzon.

Komisyon. (2005). Türkçe sözlük. Ankara: Türk Dil Kurumu.

Kuanışbayev, E. (2000). Kozu Körpeş Bayan Suluv destanı (giriş-metin-tercüme-dizin). (Yayımlanmamış Yüksek Lisans Tezi). Marmara Üniversitesi Sosyal Bilimler Enstitüsü, İstanbul.

Nas, K. Ş. (2017). Oğuz Türklerinden bugüne gelen Türk kültürünün izinden: Klâsik Türk şairlerinin dilinden and içmek. Türk Dünyası Araştırmaları, S. 230, ss.133-148.

Öztürk, G. (2001). Edige Batır destanının Başkurt versiyonu. (Yayımlanmamış Yüksek Lisans Tezi). Marmara Üniversitesi Türkiyat Araştırmaları Enstitüsü, İstanbul.

Serginbayev, M. J. (2007). Kazak destanları 4. (F. Türkmen-M. Arıkan, Çev. ). Ankara: TDK.

Subaşı, A. (1995). Seytek/Külçoro ile Ayçürök'ün yakalanışı (inceleme-metin-aktart-dizin). (Yayımlanmamış Yüksek Lisans Tezi). Marmara Üniversitesi Türkiyat Araştırmaları Enstitüsü, İstanbul. 
Sulti, R. (1998). Edigey. Ankara: TÜRKSOY.

Turgunbayev, C. (1996). Er Töştük destanında bildirme kipleri çekimleri. (Yayımlanmamış Yüksek Lisans Tezi). Çukurova Üniversitesi Sosyal Bilimler Enstitüsü, Adana.

Urmançı, F. (2007a). Tatar destanları 1. ( V. Kartalcık, C. Kerimoğlu, Çev. ). Ankara: TDK.

Urmançı, F. (2007b). Tatar destanları 2. ( V. Kartalcık, C. Kerimoğlu, Çev.). Ankara: TDK.

Uygur, C. V. (2007). Karakalpak destanları. Ankara: TDK.

Ünal, O. (2013). Ant kelimesinin kökeni üzerine. Yemin kitabı. (E. G. Naskali, Ed.). (ss.225-233). İstanbul: Kitabevi.

Yarc1, G. (2013). Osmanlı'da yemin ve tahlif. Yemin kitabı. ( E. G. Naskali, Ed.). (ss. 17-71). İstanbul: Kitabevi. 